\title{
Selection and Treatment of Stripper Gas Wells for Production Enhancement in the Mid-Continent
}

\author{
Award No. DE-FG26-00NT40789 \\ Quarterly Technical Report \\ Period: $\underline{10 / 1 / 2001-12 / 31 / 2001}$
}

Scott Reeves

March, 2003

Advanced Resources International 9801 Westheimer, Suite 805 Houston, Texas 77042 


\section{Disclaimers}

\section{U.S. Department of Energy}

This report was prepared as an account of work sponsored by an agency of the United States Government. Neither the United Sates Government nor any agency thereof, nor any of their employees, makes any warranty, express or implied, or assumes any legal liability or responsibility for the accuracy, completeness, or usefulness of any information, apparatus, product, or process disclosed, or represents that its use would not infringe privately owned rights. Reference herein to any specific commercial product, process, or service by trade name, trademark, manufacturer, or otherwise does not necessarily constitute or imply its endorsement, recommendation, or favoring by the United States Government or any agency thereof. The views and opinions of authors expressed herein do not necessarily state or reflect those of the United Sates Government or any agency thereof.

\section{$\underline{\text { Advanced Resources International }}$}

The material in this Report is intended for general information only. Any use of this material in relation to any specific application should be based on independent examination and verification of its unrestricted applicability for such use and on a determination of suitability for the application by professionally qualified personnel. No license under any Advanced Resources International, Inc., patents or other proprietary interest is implied by the publication of this Report. Those making use of or relying upon the material assume all risks and liability arising from such use or reliance. 


\begin{abstract}
Stripper gas wells are an important source of domestic energy supply and under constant threat of permanent loss (shut-in) due to marginal economics. In 1998, 192 thousand stripper gas wells produced over a Tcf of gas, at an average rate of less than $16 \mathrm{Mcfd}$. This represents about $57 \%$ of all producing gas wells in the onshore lower- 48 states, yet only $8 \%$ of production. Reserves of stripper gas wells are estimated to be only $1.6 \mathrm{Tcf}$, or slightly over $1 \%$ of the onshore lower-48 total (end of year 1996 data). Obviously, stripper gas wells are at the very margin of economic sustenance. As the demand for natural gas in the U.S. grows to the forecasted estimate of over 30 Tcf annually by the year 2010, supply from current conventional sources is expected to decline. Therefore, an important need exists to fully exploit known domestic resources of natural gas, including those represented by stripper gas wells.

The overall objectives of this project are to develop an efficient and low-cost methodology to broadly categorize the well performance characteristics for a stripper gas field, identify the highpotential candidate wells for remediation, and diagnose the specific causes for well underperformance. With this capability, stripper gas well operators can more efficiently and economically produce these resources and maximize these gas reserves. A further objective is to identify/develop, evaluate and test "new and novel," economically viable remediation options. Finally, it is the objective of this project that all the methods and technologies developed in this project, while being tested in the Mid-Continent, be widely applicable to stripper gas wells of all types across the country.
\end{abstract}

The project activities during the reporting period were:

- Type curve matching continued during the reporting period.

- A second data collection trip to Tulsa was performed to gather information on the additional reservoirs to be included in the analysis. Created updated database. Delivered information for both type-curve and artificial neural network analysis to analytic team.

- Made presentations on the project at the Stripper Well Consortium Meetings in Oklahoma City (October 24) and Dallas (October 25).

- Made presentations on the project at the PTTC Marginal Well workshop in Jackson (October 30 ) and Wichita (November 29). 


\section{Table of Contents}

Page

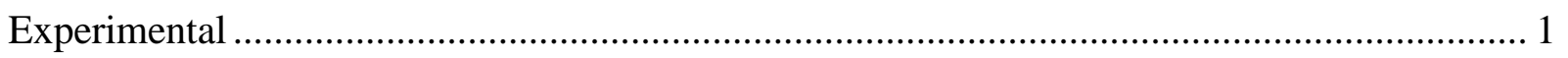

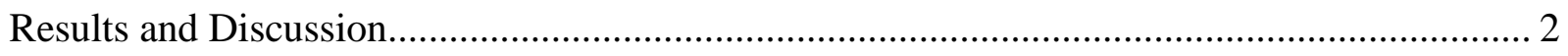

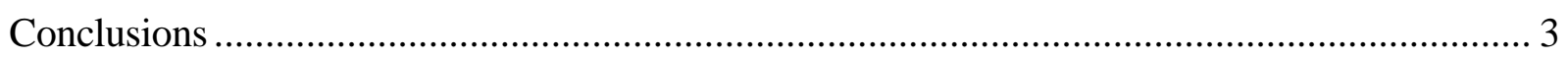

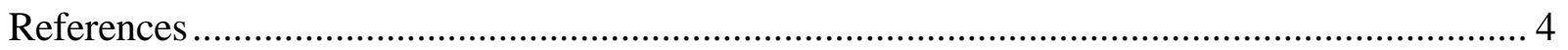




\section{Experimental}

For the subject period, the following activities were performed:

- Type curve matching continued during the reporting period.

- A second data collection trip to Tulsa was performed to gather information on the additional reservoirs to be included in the analysis. Created updated database. Delivered information for both type-curve and artificial neural network analysis to analytic team.

- Made presentations on the project at the Stripper Well Consortium Meetings in Oklahoma City (October 24) and Dallas (October 25).

- Made presentations on the project at the PTTC Marginal Well workshop in Jackson (October 30) and Wichita (November 29). 


\section{Results and Discussion}

Technical progress is now being made on the project, with the additional data from the MocaneLaverne field collected and type-curve matching nearly complete. 


\section{Conclusions}

There are no technical conclusions for the reporting period. 


\section{References}

None. 